\title{
MACC1 silencing inhibits cell proliferation and induces cell apoptosis of lung adenocarcinoma cells through the $\beta$-catenin pathway
}

\author{
L. GUO, S. OU, X. MA, S. ZHANG, Y. LAI* \\ Department of Cardiothoracic Surgery, Beijing Anzhen Hospital, Capital Medical University, Beijing 100029, People’s Republic of China \\ *Correspondence: anzhenlaiyongqiang@126.com
}

Received September 18, 2017/ Accepted November 3, 2017

\begin{abstract}
It has been documented that over-expression of metastasis-associated in colon cancer-1 (MACC1) is related to poor prognosis in non-small cell lung cancer (NSCLC). This study investigates the function and underlying molecular mechanisms of MACC1 in lung adenocarcinoma. Here, we firstly employed immunohistochemistry, western blotting, real-time PCR, and online database to demonstrate that MACC1 expression was elevated in tumor tissues compared with tumoradjacent or normal tissues. Real-time PCR, CCK-8, colony formation western blotting, Hoechst staining, and flow cytometry assays then evaluated the effects of MACC1 knockdown on the cell cycle, cell proliferation and apoptosis in A549 and H1299 adenocarcinoma cells. Result highlighted that MACC1 knockdown inhibited cell proliferation, induced G0/ G1 phase arrest and promoted cell apoptosis in vitro. Mechanistic analysis revealed it also up-regulated expression levels of bax, cleaved-caspase- 3 and cleaved-PARP while down-regulating cyclin D1, c-myc, bcl-2, and $\beta$-catenin expression in A549 cells. Intriguingly, up-regulation of $\beta$-catenin suppressed G0/G1 phase arrest and apoptosis in MACC1-silenced A549 cells and this was accompanied by increased levels of cyclin D1, c-myc, and bcl-2. Collectively, our results indicate that MACC1 knockdown effectively inhibited cell proliferation and promoted apoptosis of lung adenocarcinoma cells by regulating the $\beta$-catenin pathway.
\end{abstract}

Key words: MACC1, lung adenocarcinoma, cell cycle, cell apoptosis, $\beta$-catenin

Lung cancer has the highest mortality rate of all malignant tumors and it accounts for $27 \%$ of deaths in males and $26 \%$ in females. [1]. Non-small cell lung cancer (NSCLC), comprising adenocarcinoma, squamous carcinoma and large cell carcinoma, is the most frequently diagnosed pathology in lung cancer [2]. Although advanced development of NSCLC treatment including surgery, radiotherapy and chemotherapy has been achieved and has improved patient survival, the 5 year survival rate of patients with NSCLC is still only $15 \%$ [3], and therefore development of novel drugs and exploration of therapeutic targets are extremely urgent for NSCLC prevention and cure.

Metastasis-associated in colon cancer-1 (MACC1) is a pivotal regulator of the HGF/c-Met signal pathway and is initially identified by whole-genome expression analysis of primary and metastatic colon carcinomas [4]. Accumulating evidence reveals that MACC1 is over-expressed and associated with poor prognosis in many tumors; especially hepatocellular carcinoma [5] and gastric [6], breast [7] and colorectal cancers [8]. However, MACC1 knockdown can inhibit cell proliferation, colony formation, invasion, arrest the cell cycle in the G0/G1 phase and induce cell apoptosis in human osteosarcoma [9]. While it has been reported that high MACC1 levels predict worse prognosis in NSCLC patients [10-12], its function and underlying molecular mechanisms remain unclear.

This study evaluates MACC1 expression in adenocarcinoma samples and determines its knockdown effects on the cell cycle, cell proliferation and apoptosis in lung adenocarcinoma cells in vitro. Finally, the MACC1 silencing molecular mechanisms producing the anti-cancer effect are also investigated.

\section{Patients and methods}

Patients and tissue samples. A total of 8 paired tissue samples including corresponding normal tissue derived from patients with lung adenocarcinoma were obtained from the Department of Cardiothoracic Surgery, Beijing Anzhen Hospital. Signed informed consent was obtained 
from all participating patients and the study was approved by the Ethics Committee of Beijing Anzhen Hospital and conducted in accordance with the 2008 Declaration of the World Medical Association in Helsinki

Cell culture. Lung adenocarcinoma cell line A549 was obtained from the Shanghai Cell Bank of the Chinese Academy of Sciences and H1299 was purchased from the Chinese Food and Drug Inspection Institute. The two cell lines were cultured in Dulbecco Modified Eagle Medium (Gibco, Erie County, NY, USA) with $10 \%$ fetal calf serum (Hyclone, Logan, UT, USA), and then placed in an incubator with constant humidity at $37^{\circ} \mathrm{C}$ and $5 \% \mathrm{CO}_{2}$.

Western blot. Western blot analysis was routinely performed as previously described. In brief, whole proteins were extracted from cells and tissues with lysis buffer under low temperature. The mixture was separated with $10 \%$ SDS-PAGE and transferred onto polyvinylidene difluoride (PVDF) membranes. These were sealed with 5\% milk and incubated overnight at $4{ }^{\circ} \mathrm{C}$. by primary antibodies against MACC1 (1:500, Bioss, bs-4293R), cyclin D1 (1:500, Boster, BA0770), c-myc (1:500, Sangon, D199941), cleaved-caspase-3 (1:1000, Abcam, ab2302), bcl-2 (1:500, sangon, D198628), bax (1:500, sangon, D120073), cleaved-PARP (1:1000, Abcam, ab32561), $\beta$-catenin (1:500, KeyGen, KG21520), and $\beta$-actin (1:1000, Santa cruz, sc-47778). Target proteins were probed with HRP-labeled second antibodies and detected by enhanced chemiluminescence (Beyotime, Haimen, China) in a gel imaging system (Liuyi, Beijing, China). Target protein expression was normalized to $\beta$-actin expression.

Total RNA extraction and real-time PCR. Total RNA was isolated from tissue samples by RNApurel Kit (BioTeke, Beijing, China). Reverse transcription PCR synthesized CDNA and MACC1 expression was detected with real-time PCR and calculated by $2^{-\Delta \Delta C T}$. The primer sequences were as follows: MACC1 forward: 5'-CACAACTTGCGGAGGTCAC-3', MACC1 reverse: 5'-TTCCAACAACGGGCTCACAG-3'; $\beta$-actin forward: 5'-CTTAGTTGCGTTACACCCTTTCTTG-3', $\beta$-actin reverse: 5'-CTGTCACCTTCACCGTTCCAGTTT-3'.

Immunohistochemistry. Immunohistochemical staining determined the level of MACC1 in tissue samples. Briefly, histological sections were de-waxed with xylene and hydrated with graded ethanol. After antigen retrieval by microwave irradiation with citrate buffer solution for $10 \mathrm{~min}, 3 \% \mathrm{H}_{2} \mathrm{O}_{2}$ was applied at room temperature for 15 minutes to eliminate endogenous peroxidase activity. Sections were then incubated overnight at $4{ }^{\circ} \mathrm{C}$ with primary antibody against MACC1, and horseradish peroxidase-labeled second antibody probed the primary antibody. The target gene was visualized with DAB after hematoxylin counterstained the nucleus. Photographs were captured on optic microscope (Olympus, Tokyo, Japan) and analyzed by professionals.

Vector construction and transfection. MACC1-specific sequences were designed and nonspecific sequences synthesized as follows: MACC1 sh-RNA: 5'-GATCCCCCACCA-
TAGCTTGCAAAGTATTCAAGAGATACTTTGCAAGCTATGGTGTTTTT-3'; NC shRNA: 5'-GATCCCCTTCTCCGAACGTGTCACGTTTCAAGAGAACGTGACACGTTCGGAGAATTTTT-3’. The synthesized sequences were constructed in pGCsi-H1 plasmids and transiently transfected into A549 and H1299 cells with Lipofectamine 2000 agent (Invitrogen, Carlsbad, CA). The A549 cells were then selected by $\mathrm{G} 418$ at $500 \mathrm{~g} / \mathrm{ml}$ concentration to establish the stable cell line. The $\beta$-catenin S33Y plasmid was purchased from AddGene (Cambridge, MA, USA) and transiently transfected into stable MACC1-silenced A549 cells with Lipofectamine 2000.

Colony formation assay. Cell proliferation capacity was evaluated by colony formation assay. In brief, 300 cells were seeded in $35 \mathrm{~mm}$ dishes and placed in the incubator for two weeks. $4 \%$ paraformaldehyde then fixed cells for 20 minutes at ambient temperature. Wright-Giemsa stain dyed cells for 5 minutes. (Nanjing Jiancheng Bioengineering Institute, Nanjing, China), and the number of clones was counted by inverted microscope (Motic, Xiamen, Fujian, China).

CCK-8 assay. Cell proliferation was examined by CCK-8 kit (Beyotime). Cells at $3 \times 10^{3}$ density were seeded in a 96-well plate with five duplicates in each group. The supernatant was discarded after 24 hours, $100 \mu \mathrm{l}$ complete medium was supplemented and $10 \mu \mathrm{l}$ of CCK- 8 was then added to each well for 1 hour. Optical density (OD) was detected at $450 \mathrm{~nm}$ by microplate reader (Biotek, Winooski, USA).

Cell cycle analysis. Beyotime cell cycle kit analyzed cell cycle distribution. Cells were collected and immobilized with pre-cooled $70 \%$ ethanol at $4{ }^{\circ} \mathrm{C}$ for 2 hours and $25 \mu \mathrm{l}$ propidium iodide (PI) was added to cells re-suspended in $500 \mu \mathrm{l}$ buffer. The cells were then incubated with $10 \mu \mathrm{l}$ RNase in the dark at $3{ }^{\circ} \mathrm{C}$ for 30 minutes and the cell cycle was detected by flow cytometry (BD Biosciences, Franklin Lakes, NJ USA).

Cell apoptosis analysis. The KeyGEN, Nanjing, China apoptosis assay kit detected cell apoptosis. Cells were collected and re-suspended in $500 \mu \mathrm{l}$ binding buffer and $5 \mu \mathrm{l}$ AnnexinV-FITC was added and well-mixed. The cells were then incubated with $5 \mu \mathrm{PI}$ at room temperature for 15 minutes and apoptosis was analyzed by flow cytometry (BD Biosciences).

Hoechst staining. Beyotime Hoechst staining kit assessed cell apoptosis Cells at $5 \times 10^{4}$ density were seeded on glass slides loaded into a 12 -well plate. After 24 hours the cells were fixed with stationary liquid for 20 minutes and $0.5 \mathrm{ml}$ Hoechst staining solution was added to the plate for 5 minutes. Antiquenching agent maintained fluorescence intensity and cells were observed under an Olympus fluorescence microscope at $400 \times$ optical amplification.

Statistical analysis. Data was analyzed by Student's t-test and analysis of variance by Graphpad prism 5.0 (GraphPad Software, San Diego, CA, USA); each experiment was in triplicate and data was presented as mean \pm SD (standard deviation). $\mathrm{P}<0.05, \mathrm{p}<0.01$ and $\mathrm{p}<0.001$ were marked “*” " $* \star *$ ” and "***”, and considered statistically significant. 


\section{Results}

Expression level of MACC1 in lung adenocarcinoma. Determination of MACC1 expression in lung adenocarcinoma was performed by collecting 8 paired tissue samples of carcinoma and adjacent tissues and performing immunohistochemistry, western blotting and real-time PCR. Figures 1A, $\mathrm{C}$, and D reveal a remarkably high level of MACC1 in tumor tissues compared to adjacent tissues. Representative MACC1 immunohistochemical images in both tissue types are shown in Figure 1B. Similarly, data derived from the Oncomine database (www.oncomine.org) established that MACC1 mRNA expression in 226 lung adenocarcinoma samples was significantly higher than that seen in normal lung samples (Figure 1E). These results indicate that MACC1 has an important role in lung adenocarcinoma progression.
Silencing MACC1 in lung adenocarcinoma cells. We instituted MACC1 knockdown in A549 and H1299 cells to fully investigate MACC1 effects on lung adenocarcinoma. This process is described in the materials and methods section. The MACC1 knockdown efficiency in the two cells was evaluated by western blotting and real-time PCR. Figures 2A and B highlight that MACC1 expression was significantly reduced after silencing compared to control cell expression.

MACC1 knockdown effects on cell proliferation, cell cycle and apoptosis in lung adenocarcinoma cells. We examined if MACC1 plays any role in lung adenocarcinoma cell cycle and proliferation. Figure $3 \mathrm{~A}$ highlights that MACC1 knockdown significantly attenuated clone formation ability in A549 and H1299 cells compared to controls. The CCK- 8 assay revealed that MACC1 down-regulation
A

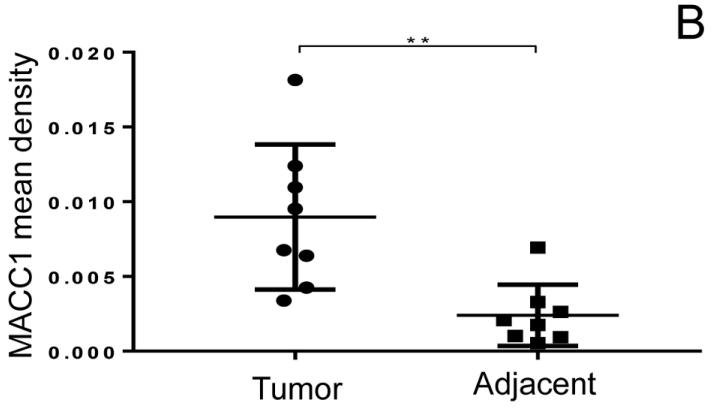

B

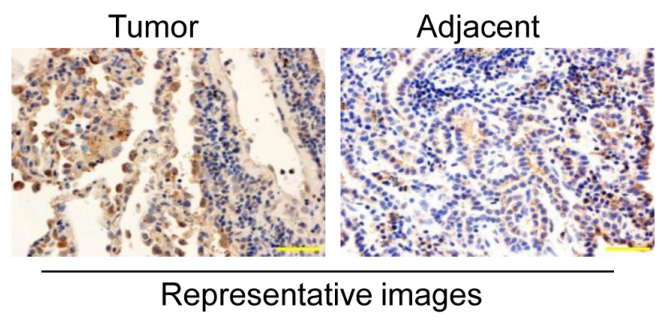

\section{C}

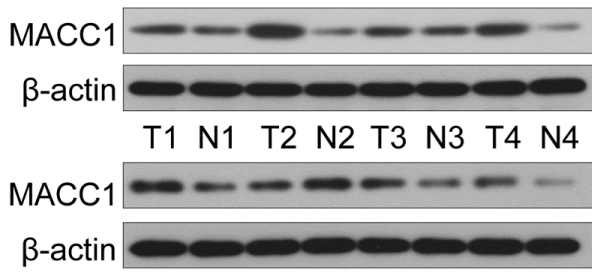

$\begin{array}{llllllll}\text { T5 } & \text { N5 } & \text { T6 } & \text { N6 } & \text { T7 } & \text { N7 } & \text { T8 } & \text { N8 }\end{array}$

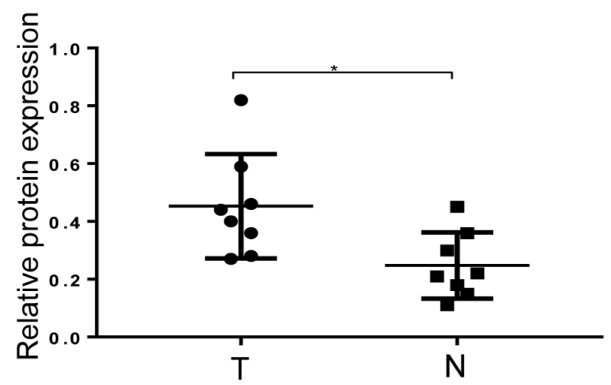

D
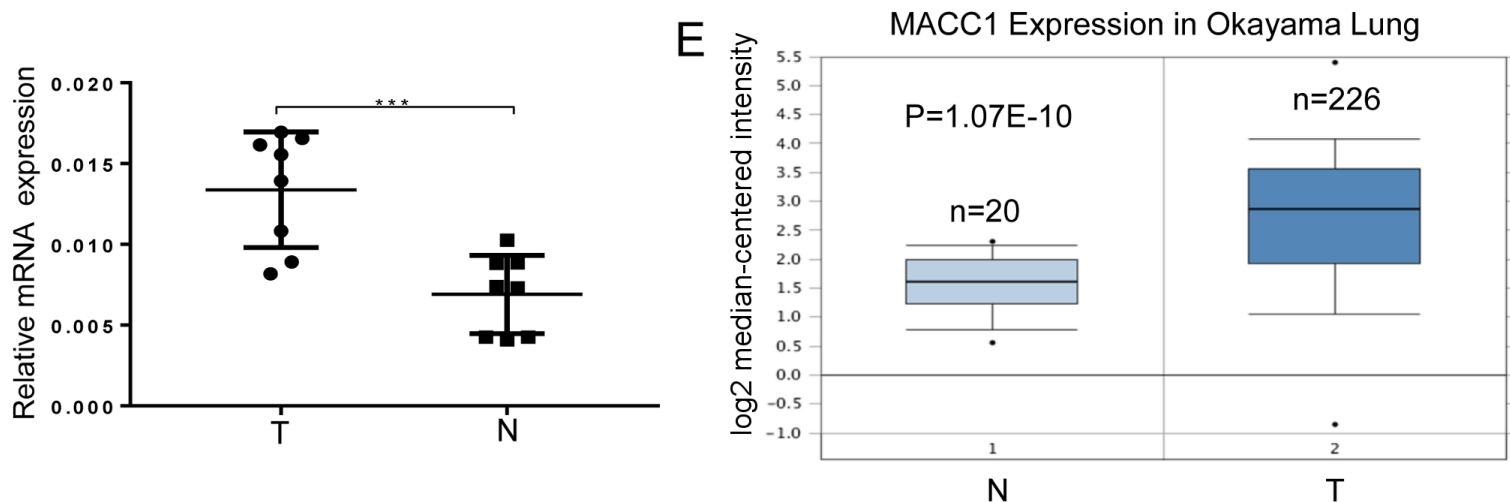

Figure 1. MACC1 is over-expressed in patients with lung adenocarcinoma. (A) Immunohistochemical analysis, (C) western blotting, and (D) real-time PCR assessed MACC1 expression in patients with lung adenocarcinoma. (B) Representative pictures of MACC1 in carcinoma and adjacent tissue. (E) MACClexpression from the oncomine database. All results are presented as means \pm SD. 
A
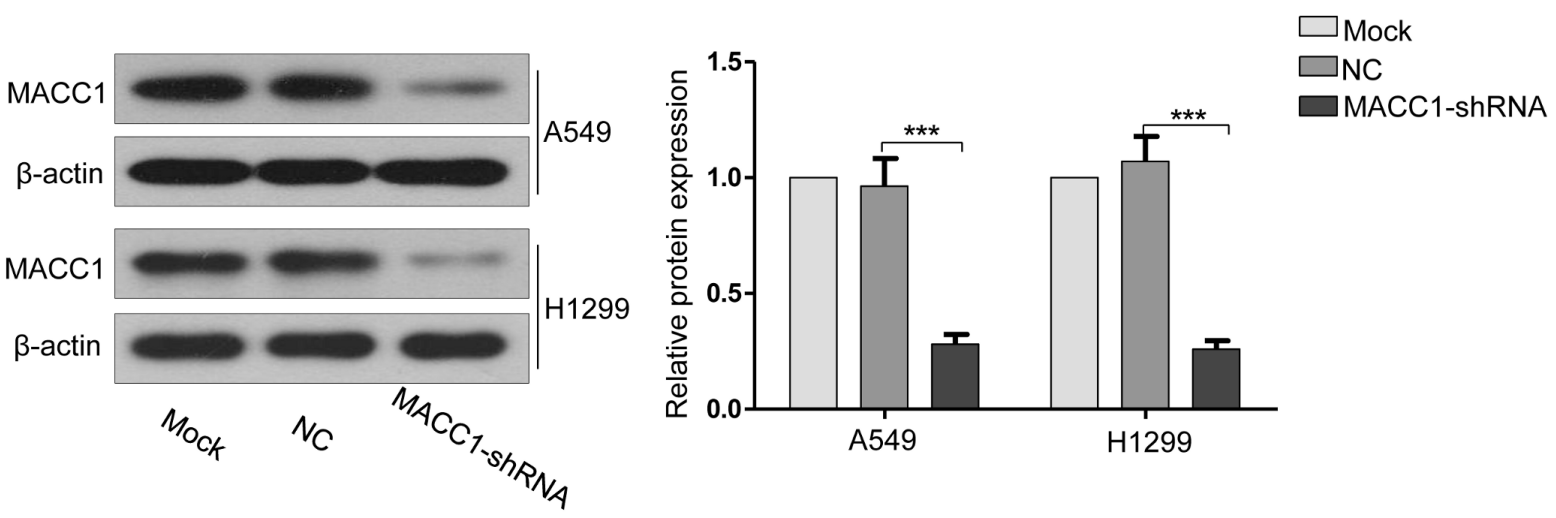

B

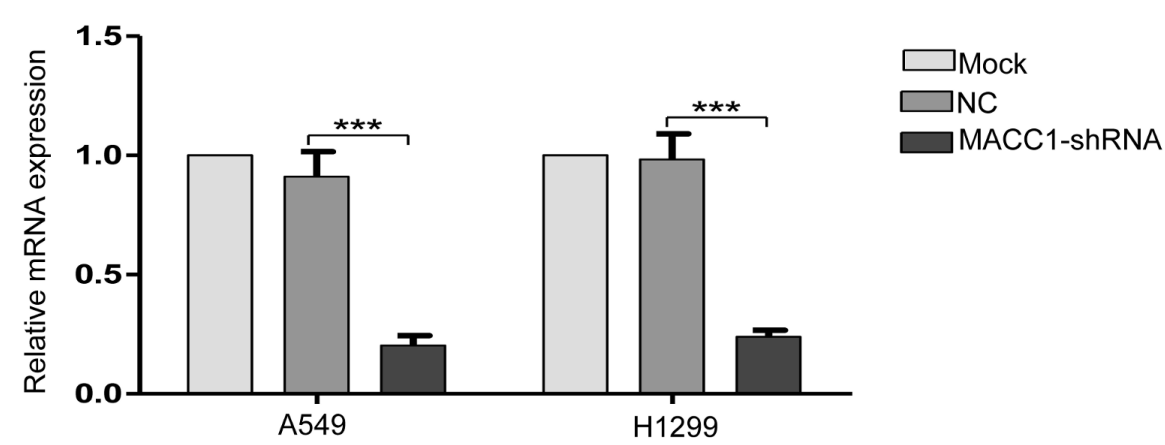

Figure 2. Verification of MACC1 knockdown efficiency in lung adenocarcinoma cells. MACC1 expression in A549 and H1299 cells was evaluated by (A) western blot and (B) real-time PCR after MACC1 silencing. Results are in means \pm SD.

inhibited A549 and H1299 cell proliferation (Figure 3B). Moreover, MACC1 silencing resulted in G0/G1 stage arrest in those two cells (Figure 3C). We also investigated MACC1 effect on adenocarcinoma cell apoptosis and Figures $4 \mathrm{~A}$ and B show that MACC1 knockdown induced apoptosis in A549 and H1200 cells compared to matched controls.

MACC1 knockdown inhibition of lung adenocarcinoma cell growth through the $\beta$-catenin pathway. We detected expression levels of the cell proliferation/apoptosisrelated genes at the molecular level. The Figure 5 results of western blot assay show that MACC1 silencing up-regulated the expression of cleaved-caspase-3, bax and cleaved-PARP in lung A549 cells but down-regulated cyclin D1, c-myc, bcl-2 and $\beta$-catenin. Intriguingly, the G0/G1 stage arrest in MACC1-silenced A549 cells was relieved following up-regulation of $\beta$-catenin (Figure 6A). Similarly, apoptosis in MACC1-silenced A549 cells was decreased by $\beta$-catenin over-expression (Figures $6 \mathrm{~B}$ and $\mathrm{C}$ ). Moreover, increased $\beta$-catenin was found to up-regulate the expression levels of cyclin D1, c-myc, and bcl-2 in MACC1-silenced A549 cells (Figure 6D).

\section{Discussion}

Lung cancer is one of the commonest global malignancies that pose serious threat to human health. Non-small cell lung cancer (NSCLC) is the most frequent type, and this accounts for up to $85 \%$ of all pathological lung cancers [10]. Although great improvement has been made in treating malignant tumors, a huge challenge remains to improve NSCLS patient survival and lessen the terrible mortality rate [3].

Our study proves that MACC1 is elevated in patients with lung adenocarcinoma and that MACC1 knockdown significantly attenuates proliferation capability, induces G0/ G1 phase arrest and stimulates cell apoptosis in vitro in lung adenocarcinoma cells by regulating the $\beta$-catenin pathway. MACC1 elevated expression and prognostic value have been demonstrated in multiple tumors $[6,10,14-18]$, and our results of tissue samples and database search coincide with the well-documented NSCLC data provided by Wang et al. and Zhou et al. $[10,11]$. Numerous studies on the correlation between MACC1 expression and clinical pathological parameters indicate its prognostic value in a variety of cancers $[5,8,19]$. Following Wang et al. [20], we explored MACC1's additional functions and the underlying molecular mechanisms

Uncontrolled cell proliferation and inhibition of normal apoptosis can result in cancer [21]. MACC1 has been demonstrated to be over-expressed in the A549 and H1299 cell lines $[10,22]$ and here we confirmed that finding and proved further that MACC1 silencing inhibited cell proliferation and induced cell apoptosis and cycle arrest of G0/G1 in A549 

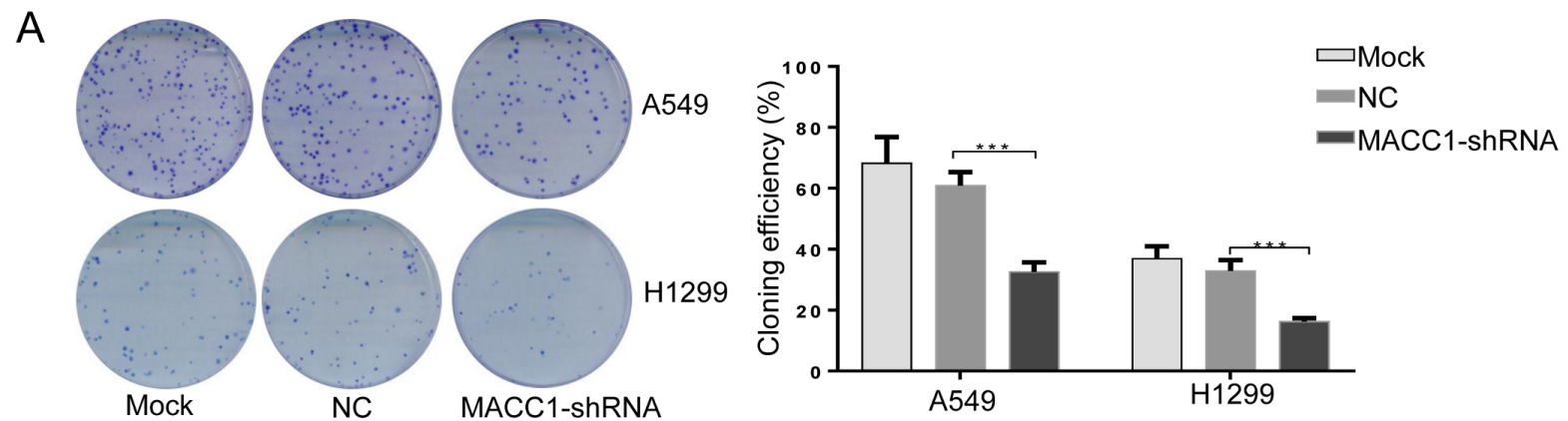

B
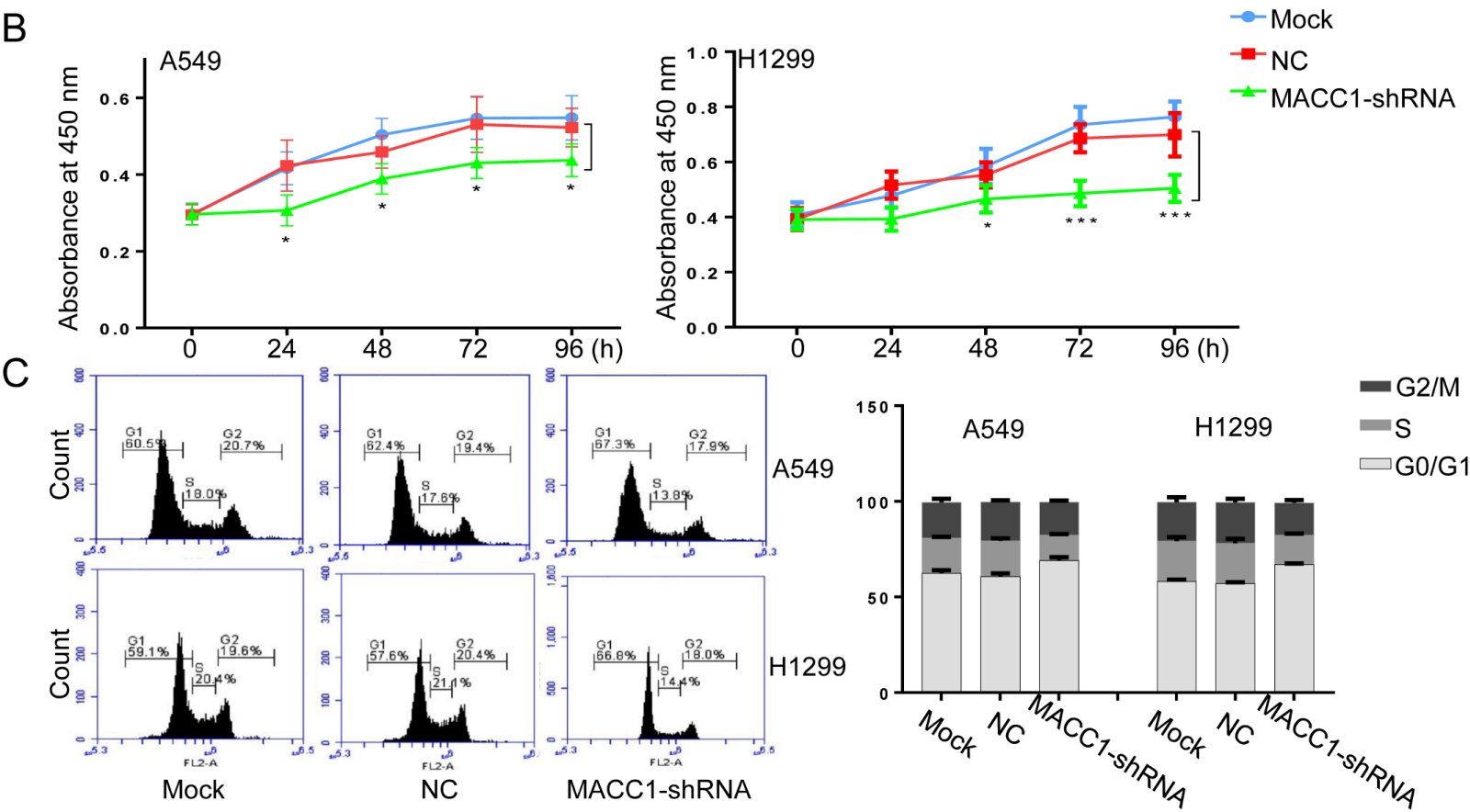

Figure 3. MACC1 silencing suppressed proliferation and induced G0/G1 stage arrest in lung adenocarcinoma cells. (A) detection of colony-formation viability and (B) proliferation ability of A549 and H1299 cells after MACC1 silencing. (C) Flow cytometry analysis of the effect of MACC1 knockdown on cell cycle distribution in A549 and H1299 cells. Results are presented as means \pm SD.

and H1299 cells in vitro. Cyclin D1 is a key checkpoint of cell division from the G1 to $S$ phase which binds its cyclin dependent kinases (CDKs) to regulate cell growth [23]. There are also extensive literature reports that Cyclin D1 plays an important role in various cancers, including NSCLC cancer [24-27].

The programmed cell death in apotosis in extrinsic, mitochondrial and endocytoplasmic reticulum pathways is a crucial process in the body's development, and unregulated cell growth occurs and tumors develop when this process is impeded [28]. The Bcl-2 family proteins can regulate cell death by controlling mitochondrial membrane permeability; and this includes both the pro-apoptotic proteins, such as Bak and Bax) [29] and the anti-apoptotic proteins which include Bcl-2, Bcl-XL and Mcl-1 [29]. The Bcl-2 protein, for example, impairs caspase activity by preventing the release of cytochrome $\mathrm{c}$ from the mitochondria and/or by binding with the Apaf-1 apoptotic-activating factor [30]. The increase in cleaved-PARP caspase- 3 substrate indicates MACC1 knockdown's pro-apoptotic effect in the lung adenocarcinoma cell [31].

MACC1 anti-cancer mechanisms have been extensively studied in a variety of tumors. For example; (1) Akt signaling is involved in the MACC1-mediated promotion of proliferation and tumorgenicity in human osteosarcoma [9]; (2) over-expression of MACC1 in colon cancer results in activation of the HGF/MET and $\beta$-catenin signal pathways $[32,33]$; (3) MACC1 enhances vasculogenic mimicry in gastric carcinoma through up-regulation of TWIST1/2 [34] and (4) multiple signaling pathways play crucial roles in NSCLC development. These include pathways for growth factor receptor (EGFR), mitogen-activated protein kinases (MAPK) and phosphatidylinositol 3-kinases (PI3K) [35, 36]. 
A

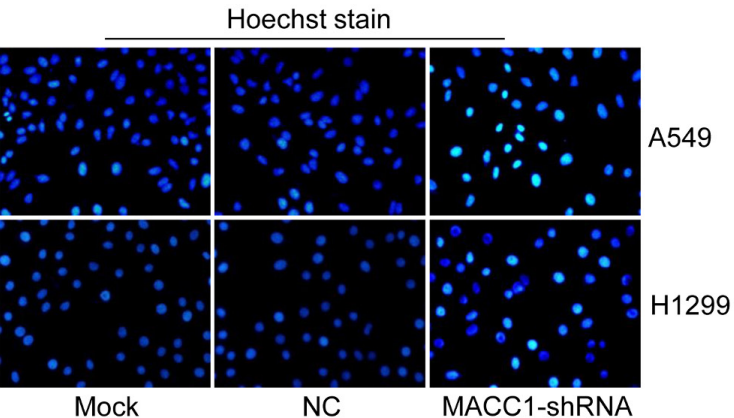

B
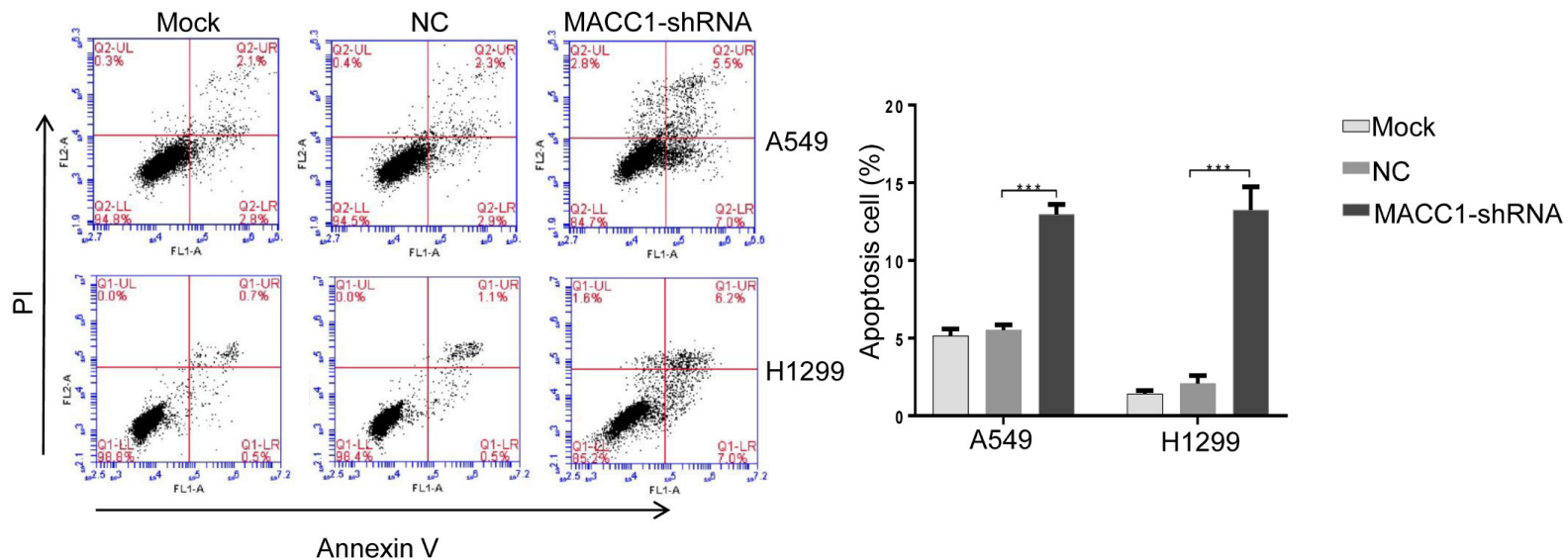

Figure 4. MACC1 silencing promoted apoptosis in lung adenocarcinoma cells. Apoptosis in A549 and H1299 cells was evaluated by (A) Hoechst stain and (B) flow cytometry after MACC1 silencing. Results are in means \pm SD.

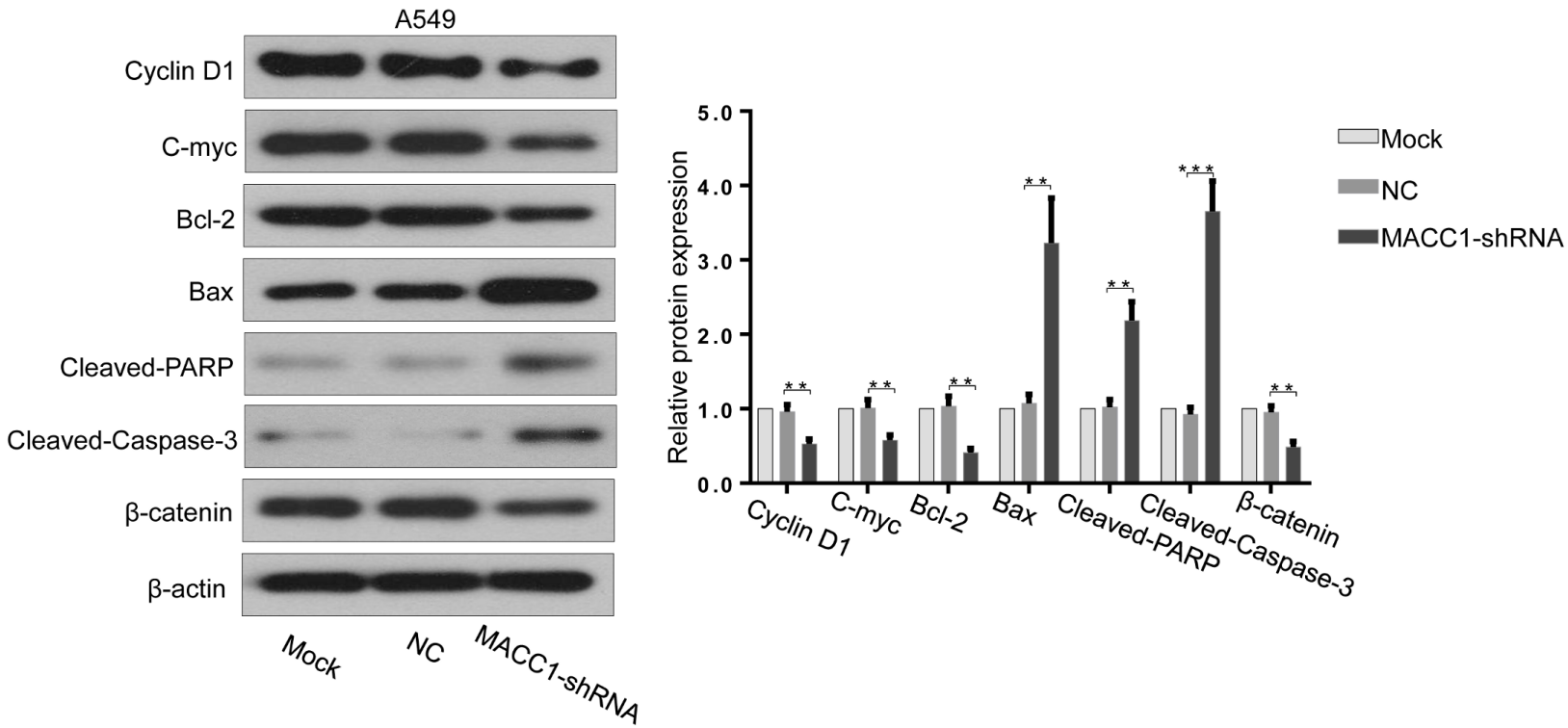

Figure 5. MACC1 silencing regulated cell cycle-, proliferation-, and apoptosis-related molecules in A549 cells. The expression levels of cyclin D1, c-myc, bcl-2, bax cleaved-PARP, cleaved-Caspase-3, and $\beta$-catenin were detected in MACC1-silenced A549 cells by western blotting. Results are presented as means \pm SD. 
A

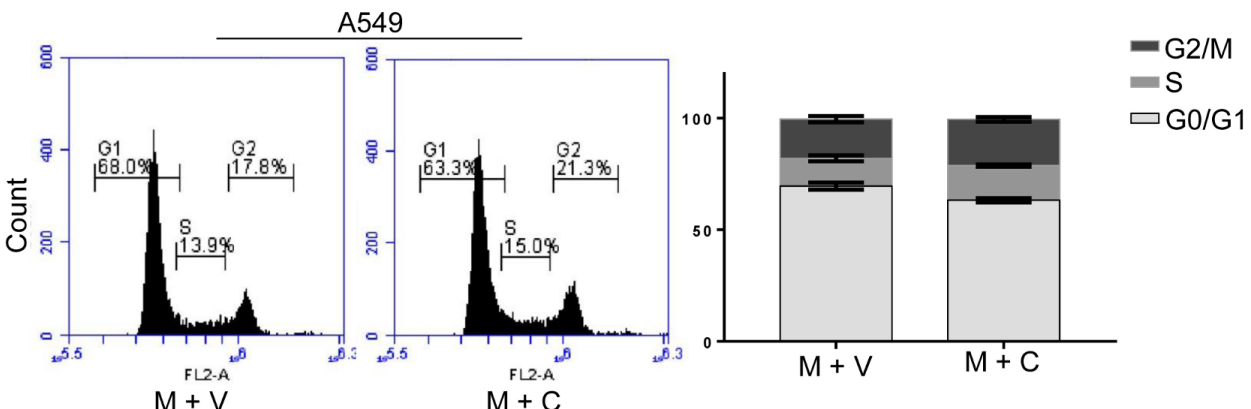

B
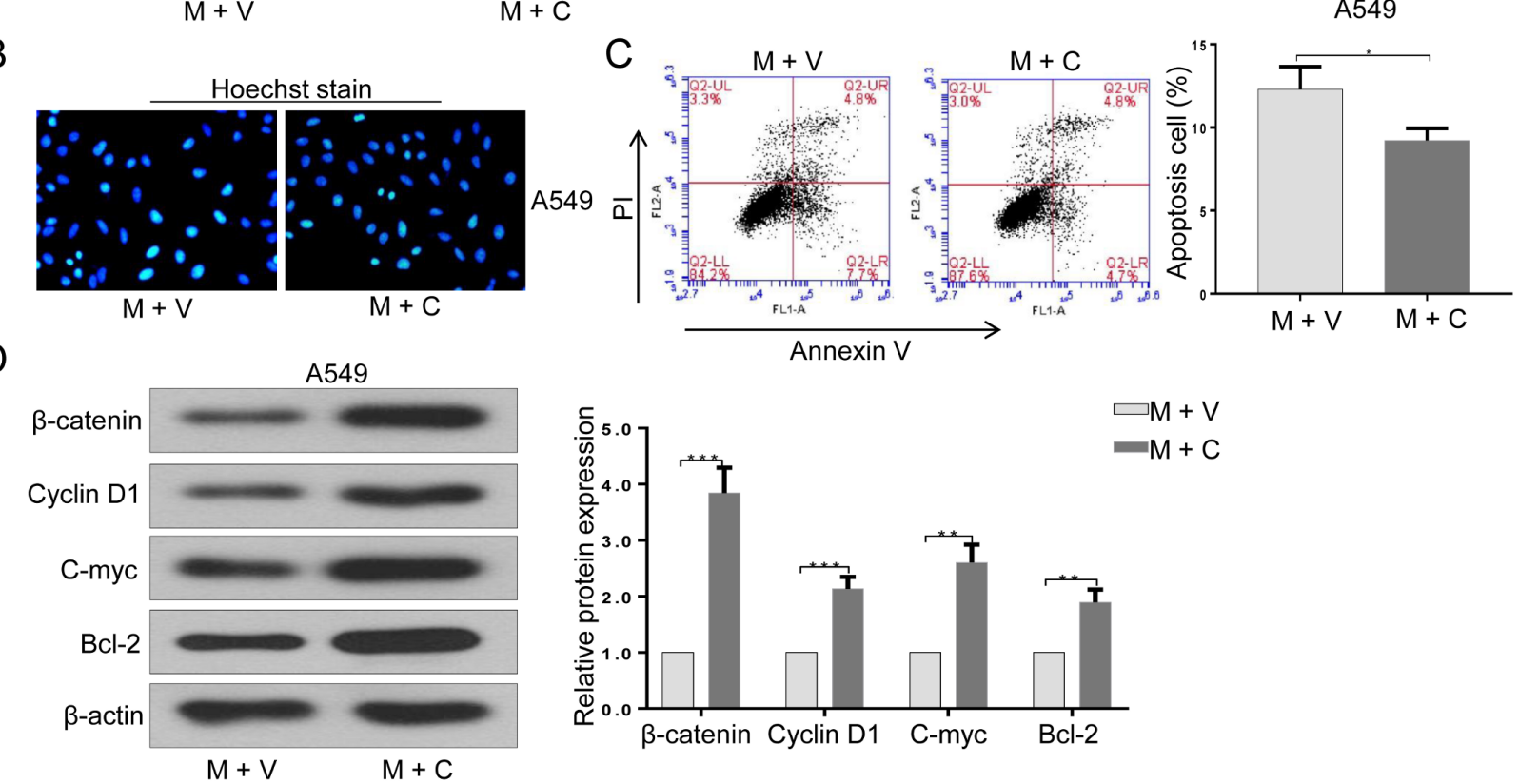

Figure 6. Up-regulation of $\beta$-catenin can reverse the MACC1 knockdown effect in A549 cells. (A) The cell cycle was evaluated in the MACC1-silenced A549 cell with over-expression of $\beta$-catenin. (B) Hoechst stain and (C) flow cytometry assessed cell apoptosis. (D) Expression levels of $\beta$-catenin, cyclin D1, c-myc and bcl- 2 were determined by western blotting. M + V, MACC1-shRNA + Vector; M + C, MACC1-shRNA + $\beta$-catenin S33Y. The results are in means $\pm \mathrm{SD}$

Lin et al. demonstrated that H19 knockdown simultaneously up-regulated MACC1 and $\beta$-catenin expression in a lung adenocarcinoma cell, and thus implied correlation between them. Herein, we demonstrated that MACC1 knockdown down-regulated the expression of $\beta$-catenin which is the central molecule in the $\beta$-catenin pathway. Moreover, our rescue experiment of $\beta$-catenin over-expression in MACC1silenced A549 cells highlighted that MACC1 knockdown effects on the cell cycle and cell apoptosis were inverted by up-regulation of $\beta$-catenin. Further, the cyclin D1, c-myc and bcl 2 downstream target genes in the $\beta$-catenin pathway $[33,37,38]$ were rescued following elevated $\beta$-catenin in MACC1-silenced A549 cells. Thus, our results indicate that the anticancer effect of MACC1 silencing is mediated by $\beta$-catenin pathway.

In conclusion, MACC1 expression was elevated in lung adenocarcinoma and its knockdown resulted in inhibition of cell proliferation and increased cell apoptosis in lung adenocarcinoma cells in vitro. These findings provide new insight into the molecular mechanisms of the anti-cancer effect of MACC1 knockdown in lung adenocarcinoma, strongly suggesting MACC1 as a therapeutic target for the treatment of this cancer.

\section{References}

[1] SIEGEL RL, MILLER KD, JEMAL A. Cancer statistics, 2016. CA Cancer J Clin 2016; 66: 7-30. https://doi.org/10.3322/ caac. 21332

[2] MARQUEZ-GARBAN DC, MAH V, ALAVI M, MARESH EL, CHEN HW et al. Progesterone and estrogen receptor expression and activity in human non-small cell lung cancer. Steroids 2011; 76: 910-920. https://doi.org/10.1016/j. steroids.2011.04.015 
[3] KAMANGAR F, DORES GM, ANDERSON WF. Patterns of cancer incidence, mortality, and prevalence across five continents: defining priorities to reduce cancer disparities in different geographic regions of the world. J Clin Oncol 2006; 24: 2137-2150. https://doi.org/10.1200/JCO.2005.05.2308

[4] STEIN U, WALTHER W, ARLT F, SCHWABE H, SMITH J et al. MACC1, a newly identified key regulator of HGF-MET signaling, predicts colon cancer metastasis. Nat Med 2009; 15: 59-67. https://doi.org/10.1038/nm.1889

[5] SUN DW, ZHANG YY, QI Y, LIU GQ, CHEN YG et al. Prognostic and clinicopathological significance of MACC1 expression in hepatocellular carcinoma patients: a metaanalysis. Int J Clin Exp Med 2015; 8: 4769-4777.

[6] XIE QP, XIANG C, WANG G, LEI KF, WANG Y. MACC1 upregulation promotes gastric cancer tumor cell metastasis and predicts a poor prognosis. J Zhejiang Univ Sci B 2016; 17: 361-366. https://doi.org/10.1631/jzus.B1500236

[7] HUANG Y, ZHANG H, CAI J, FANG L, WU J et al. Overexpression of MACC1 and Its significance in human Breast Cancer Progression. Cell Biosci 2013; 3: 16. https://doi. org/10.1186/2045-3701-3-16

[8] XU L, XUAN Z, LIN G, QIU H, XIAO Y et al. [Expression of MACC1 protein in colorectal cancer and its relationship with clinicopathological characteristics]. Zhonghua Wei Chang Wai Ke Za Zhi 2015; 18: 1032-1035.

[9] ZHANG K, TIAN F, ZHANG Y, ZHU Q, XUE N et al. MACC1 is involved in the regulation of proliferation, colony formation, invasion ability, cell cycle distribution, apoptosis and tumorigenicity by altering Akt signaling pathway in human osteosarcoma. Tumour Biol 2014; 35: 2537-2548. https://doi.org/10.1007/s13277-013-1335-5

[10] WANG Z, LI Z, WU C, WANG Y, XIA Y et al. MACC1 overexpression predicts a poor prognosis for non-small cell lung cancer. Med Oncol 2014; 31: 790. https://doi.org/10.1007/ s12032-013-0790-6

[11] ZHOU L, YU L, ZHU B, WU S, SONG W, et al. Metastasisassociated in colon cancer- 1 and aldehyde dehydrogenase 1 are metastatic and prognostic biomarker for non-small cell lung cancer. BMC Cancer 2016; 16: 876. https://doi. org/10.1186/s12885-016-2903-Z

[12] HU X, FU X, WEN S, ZOU X, LIU Y. [Prognostic value of MACC1 and c-met expressions in non-small cell lung cancer]. Zhongguo Fei Ai Za Zhi 2012; 15: 399-403. https://doi. org/10.3779/j.issn.1009-3419.2012.07.02

[13] TORRE LA, BRAY F, SIEGEL RL, FERLAY J, LORTETTIEULENT J et al. Global cancer statistics, 2012. CA Cancer J Clin 2015; 65: 87-108. https://doi.org/10.3322/caac.21262

[14] SHIMOKAWA H, URAMOTO H, ONITSUKA T, CHUNDONG G, HANAGIRI T et al. Overexpression of MACC1 mRNA in lung adenocarcinoma is associated with postoperative recurrence. J Thorac Cardiovasc Surg 2011; 141: 895898. https://doi.org/10.1016/j.jtcvs.2010.09.044

[15] CHEN S, ZONG ZH, WU DD, SUN KX, LIU BL et al. The role of metastasis-associated in colon cancer 1 (MACC1) in endometrial carcinoma tumorigenesis and progression. Mol Carcinog 2017; 56: 1361-1371. https://doi.org/10.1002/ mc. 22599
[16] TAN W, XIE X, LI L, TANG H, YE X et al. Diagnostic and prognostic value of serum MACC1 in breast cancer patients. Oncotarget 2016; 7: 84408-84415. https://doi.org/10.18632/ oncotarget.12910

[17] KOPCZYNSKA EK. The potential therapeutic applications and prognostic significance of metastasis-associated in colon cancer-1 (MACC1) in cancers. Contemp Oncol (Pozn) 2016; 20: 273-280. https://doi.org/10.5114/wo.2016.61846

[18] ROHR UP, HERRMANN P, ILM K, ZHANG H, LOHMANN $S$ et al. Prognostic value of MACC1 and proficient mismatch repair status for recurrence risk prediction in stage II colon cancer patients: the BIOGRID studies. Ann Oncol 2017; 28: 1869-1875. https://doi.org/10.1093/annonc/mdx207

[19] DONG HM, HUANG JK, GONG XM, TAO YS. [Expressions of MACC1, Snail, and KISS-1 Proteins in Infiltrating Breast Carcinoma and Its Clinicopathological Features]. Sichuan Da Xue Xue Bao Yi Xue Ban 2016; 47: 732-737.

[20] WANG L, SUN Y, YI J, WANG X, LIANG J et al. Targeting $\mathrm{H} 19$ by lentivirus-mediated RNA interference increases A549 cell migration and invasion. Exp Lung Res 2016; 42: 346-353. https://doi.org/10.1080/01902148.2016.1223229

[21] KASTAN MB, CANMAN CE, LEONARD CJ. P53, cell cycle control and apoptosis: implications for cancer. Cancer Metastasis Rev 1995; 14: 3-15.

[22] GUO T, ZHAO S, WANG P, XUE X, ZHANG Y et al. YB-1 regulates tumor growth by promoting $\mathrm{MACC} 1 / \mathrm{c}-$ Met pathway in human lung adenocarcinoma. Oncotarget 2017; 8: 48110-48125. https://doi.org/10.18632/oncotarget.18262

[23] QIE S, DIEHL JA. Cyclin D1, cancer progression, and opportunities in cancer treatment. J Mol Med (Berl) 2016; 94: 1313-1326. https://doi.org/10.1007/s00109-016-1475-3

[24] MARAMPON F, GRAVINA GL, JU X, VETUSCHI A, SFERRA R et al. Cyclin D1 silencing suppresses tumorigenicity, impairs DNA double strand break repair and thus radiosensitizes androgen-independent prostate cancer cells to DNA damage. Oncotarget 2016; 7: 64526. https://doi. org/10.18632/oncotarget.12267

[25] RAMOS-GARCIA P, GIL-MONTOYA JA, SCULLY C, AYEN A, GONZALEZ-RUIZ L et al. An update on the implications of Cyclin D1 in oral carcinogenesis. Oral Dis 2016; 23: 897-912. https://doi.org/10.1111/odi.12620

[26] PARK H, LEE M, KIM DW, HONG SY, LEE H. Glycogen synthase kinase 3beta and cyclin D1 expression in cervical carcinogenesis. Obstet Gynecol Sci 2016; 59: 470-478. https://doi.org/10.5468/ogs.2016.59.6.470

[27] HARADA M, KOTAKE Y, OHHATA T, KITAGAWA K, NIIDA $\mathrm{H}$ et al. YB-1 promotes transcription of cyclin D1 in human non-small-cell lung cancers. Genes Cells 2014; 19: 504-516. https://doi.org/10.1111/gtc.12150

[28] GAO XL, LIN H, ZHAO W, HOU YQ, BAO YL et al. JA, a new type of polyunsaturated fatty acid isolated from Juglans mandshurica Maxim, limits the survival and induces apoptosis of heptocarcinoma cells. Apoptosis 2016; 21: 340-350. https://doi.org/10.1007/s10495-015-1202-5

[29] TSUJIMOTO Y. Role of Bcl-2 family proteins in apoptosis: apoptosomes or mitochondria? Genes Cells 1998; 3: 697707. 
[30] LINDSAY J, ESPOSTI MD, GILMORE AP. Bcl-2 proteins and mitochondria--specificity in membrane targeting for death. Biochim Biophys Acta 2011; 1813: 532-539. https:// doi.org/10.1016/j.bbamcr.2010.10.017

[31] RHEAUME E, COHEN LY, UHLMANN F, LAZURE C, ALAM A et al. The large subunit of replication factor $\mathrm{C}$ is a substrate for caspase- 3 in vitro and is cleaved by a caspase-3like protease during Fas-mediated apoptosis. EMBO J 1997; 16: 6346-6354. https://doi.org/10.1093/emboj/16.21.6346

[32] BOARDMAN LA. Overexpression of MACC1 leads to downstream activation of HGF/MET and potentiates metastasis and recurrence of colorectal cancer. Genome Med 2009; 1: 36. https://doi.org/10.1186/gm36

[33] ZHEN T, DAI S, LI H, YANG Y, KANG L et al. MACC1 promotes carcinogenesis of colorectal cancer via beta-catenin signaling pathway. Oncotarget 2014; 5: 3756-3769. https:// doi.org/10.18632/oncotarget.1993

[34] WANG L, LIN L, CHEN X, SUN L, LIAO Y et al. Metastasisassociated in colon cancer-1 promotes vasculogenic mimicry in gastric cancer by upregulating TWIST1/2. Oncotarget 2015; 6: 11492-11506. https://doi.org/10.18632/oncotarget. 3416
[35] TROIANI T, NAPOLITANO S, DELLA CORTE CM, MARTINI G, MARTINELLI E et al. Therapeutic value of EGFR inhibition in CRC and NSCLC: 15 years of clinical evidence. ESMO Open 2016; 1: e000088. https://doi.org/10.1136/esmoopen-2016-000088

[36] CIUFFREDA L, INCANI UC, STEELMAN LS, ABRAMS SL, FALCONE I et al. Signaling intermediates (MAPK and PI3K) as therapeutic targets in NSCLC. Curr Pharm Des 2014; 20: 3944-3957.

[37] FU L, ZHANG C, ZHANG LY, DONG SS, LU LH et al. Wnt2 secreted by tumour fibroblasts promotes tumour progression in oesophageal cancer by activation of the Wnt/beta-catenin signalling pathway. Gut 2011; 60: 1635-1643. https://doi. org/10.1136/gut.2011.241638

[38] LI Q, DASHWOOD WM, ZHONG X, NAKAGAMA H, DASHWOOD RH. Bcl-2 overexpression in PhIP-induced colon tumors: cloning of the rat $\mathrm{Bcl}-2$ promoter and characterization of a pathway involving beta-catenin, c-Myc and E2F1. Oncogene 2007; 26: 6194-6202. https://doi. org/10.1038/sj.onc. 1210438 